\title{
CHANGES OF THE FOREST LAND AREA AND SPATIAL STRUCTURE IN URBAN LANDSCAPES OF LITHUANIA
}

\author{
Daiva Tiškutè-Memgaudienè \\ Aleksandras Stulginskis University, Lithuania \\ daiva.memgaudiene@asu.lt
}

\begin{abstract}
The territorial planning and the management of urban surfaces force the decrease of green spaces in urban landscapes. As the urbanization process during past decades of the last century was quite intensive not only in Europe but also in Lithuania, findings describing changes of forest cover as well as spatial structure of the forest land are requested. The aim of this study was as follows: first, to calculate and compare areas of the forest land in six major cities of Lithuania in 1950 and 2011, second, to evaluate the spatial structure of the forest land by investigated cities within the period of 1950 - 2011. Methods of descriptive statistical analysis and spatial analysis using ArcGIS and MS EXCEL software were used. The study was based on two geodatabases, representing the forest cover in 1950 and 2011. Results of this study revealed that areas of the forest land increased in all investigated cities excluding Panevėžys city. The increases of areas of the forest land were discovered to vary from $0.8 \%$ to $9.5 \%$. The largest increase was found in Vilnius city $(9.5 \%)$, the smallest - in Šiauliai city $(0.8 \%)$. The decrease by $0.9 \%$ of the forest land was found just in Panevéžys city. No significant changes of the forest land spatial structure were found in largest cities of Lithuania, i. e. Vilnius city and Kaunas city. The spatial structure of forest land in other investigated cities tended to degrade.
\end{abstract}

Key words: forest land area, forest land spatial structure, urban landscape.

\section{Introduction}

Primary forests, covering entire Europe, were being destroyed due to ancient urbanization since the 9th century (Dyderski et al., 2017). Forest lands have been shifted to agricultural and urban surfaces (Juknelienè \& Mozgeris, 2015; Ruseckas \& TiškutèMemgaudienè, 2013; Tiškutè-Memgaudienè \& Ruseckas, 2014). Urban growth became extremely high in the 20 - 21 century. In 1900, only 4\% of world's population has been living in urban areas. As in 2000s, more than half world's population became citizens of the cities. The urbanization process in Lithuania developed similarly to the presented. In 1897, only $13.3 \%$ of Lithuanians lived in urban areas, as in 2000 , the population of citizens increased to $67.3 \%$ (Vaitekūnas, 2002). Although new urban surfaces grew reducing agricultural and forest land, new forest lands were generated either. Since the period just after the World War II most territories of Lithuania were afforested during voluntary meetings what made this process rough and spontaneous.

The expansion of the urban areas in recent decades pose challenges not only in rapid growth of urban population, but also in degradation and loss of green spaces, landscape fragmentation and land use changes (Grigorescu \& Geacu, 2017). Rapid urbanization and high-density of urban territories necessitates afforestation of urban and suburban areas. Urban forests provide ecological and social functions (Alberti \& Marzluff, 2004; Daniels et al., 2018; Chiesura, 2004).

Territorial planning is a key measure for the landscape formation in Lithuania (Juknelienè et al., 2017) and is regulated by Law on Territorial Planning (Lietuvos, 1995). By the implementation of territorial planning the government legitimates not only the development of engineering facilities' infrastructure, rational use of land resources but also alteration of forest land areas. The alteration of forest land in urban landscape is regulated not only by national but also by EU legislation. The European Commission developed a Green Infrastructure Strategy that aims to ensure that the restoration, creation and enhancement of green infrastructure become an integral part of territorial planning.

The aim of this study is to compare forest cover geodata in 1950 and 2011 and to evaluate the spatial structure of the forest land by six major cities of Lithuania. The findings of this study may help to understand better the peculiarities of alteration of the forest land cover in urban landscape of Lithuania as well as spatial structure of the forest land just after the World War II and to compare to that of the recent days.

\section{Materials and Methods}

Methods of descriptive statistical analysis and spatial analysis using ArcGIS and MS EXCEL software were used to collect and evaluate the data of this study.

In order to determine changes of forest land area and spatial structure in urban landscapes of Lithuania, two geodatabases of the forest cover were used: 1 . The geodatabase representing the forest cover in 1950 that was obtained using historical orthophotomaps within a period just after the World War II. The orthophotomaps based on aerial photography were scanned and georeferenced to the coordinate system of Lithuania (LKS94). The forest land was digitized and stored in a GIS format (Mozgeris, 2012). 2. The geodatabase of the forest land from the State Forest Cadastre, available from the State Forest Service, representing the forest status on Jan 1, 2011. 
Area of forest land by cities

\begin{tabular}{|c|c|c|c|c|c|c|c|}
\hline \multirow[t]{2}{*}{ City } & \multirow{2}{*}{$\begin{array}{c}\text { Area of land } \\
\text { ha }\end{array}$} & \multicolumn{2}{|c|}{ Area of forest land in 1950} & \multicolumn{2}{|c|}{ Area of forest land in 2011} & \multicolumn{2}{|c|}{$\begin{array}{l}\text { Increase/Decrease of } \\
\text { forest land area }\end{array}$} \\
\hline & & ha & $\%$ & ha & $\%$ & ha & $\%$ \\
\hline Vilnius & 40038.0 & 10559.8 & 26.4 & 14376.9 & 35.9 & 3817.2 & 9.5 \\
\hline Kaunas & 15694.2 & 2697.3 & 17.2 & 3535.1 & 22.5 & 837.9 & 5.3 \\
\hline Klaipèda & 9825.8 & 1893.0 & 19.3 & 2060.5 & 21.0 & 167.5 & 1.7 \\
\hline Šiauliai & 8109.5 & 398.2 & 4.9 & 458.7 & 5.7 & 60.6 & 0.8 \\
\hline Panevėžys & 5015.2 & 163.9 & 3.3 & 122.4 & 2.4 & -41.5 & -0.9 \\
\hline Alytus & 3943.2 & 1142.2 & 29.0 & 1303.6 & 33.1 & 161.4 & 4.1 \\
\hline
\end{tabular}

To evaluate changes of the forest land areas by cities, polygon features representing the forest cover in 1950 and 2011 were developed using ArcGIS analysis. In order to originate polygon features of the forest land in a particular territory, recent boundaries of the cities were selected. The data of forest land areas by the cities was developed using conventional ArcGIS statistics for table tool.

The method of spatial analysis was used to evaluate the spatial structure of the forest land in urban landscapes of Lithuania. Grids of Euclidean distance of cells to the nearest forests covering particular cities in 1950 and 2011 were calculated and choropleth maps were developed to illustrate the characteristics of forest spatial structure.

\section{Results and Discussions}

The data obtained for areas of the forest land in 1950 and 2011 by cities of Lithuania, revealed that forest land in investigated urban landscapes met both afforestation and deforestation (Table 1).

The increases of areas of the forest land during the investigated period were discovered to vary from $0.8 \%$ to $9.5 \%$. The most noticeable increase of the forest land area has been found in Vilnius city, i. e. by
3817.2 ha, resulting in the forest land proportion of $9.5 \%$ in 2011. In comparison, the smallest increase of the forest land area was found in Šiauliai city, i. e. by 60.6 ha, resulting in the forest land proportion of $0.8 \%$ in 2011. The increase of the forest land in Klaipeda city and Alytus city were quite similar. The area of the forest land in Klaipeda city increased by 167.5 ha, while in Alytus city - by 161.4 ha. Since the area of Klaipeda city and Alytus city differs, proportions of the forest land varies respectively: the increase of the forest land area within the period of $1950-2011$ in Klaipeda city was by $1.7 \%$ while in Alytus city by $4.1 \%$. The area of the forest land in Kaunas city increased by 837.9 ha, resulting in the forest land proportion of $5.3 \%$ in 2011 . The decrease by $0.9 \%$ (i. e. $41.5 \mathrm{ha}$ ) of the forest land within the investigated period was found just in Panevěžys city.

Further results of the study ascertained changes of the forest land spatial structure in urban landscape of Lithuania within the investigated period. Results of the forest land spatial structure should be explained as follows: the larger Euclidean distance to the forest land in urban landscape is, the higher the fragmentation of the forest land is and the lower the concentration in forest tracts is (Euclidean distance
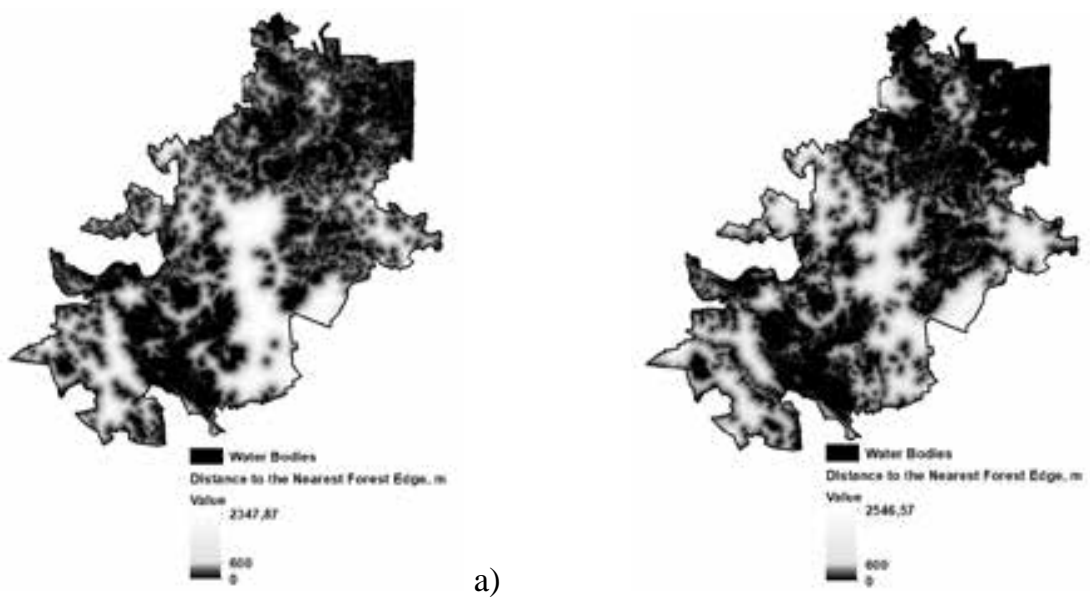

a)

b)

Figure 1. Spatial structure of forest land in Vilnius city: a) in 1950; b) in 2011. 


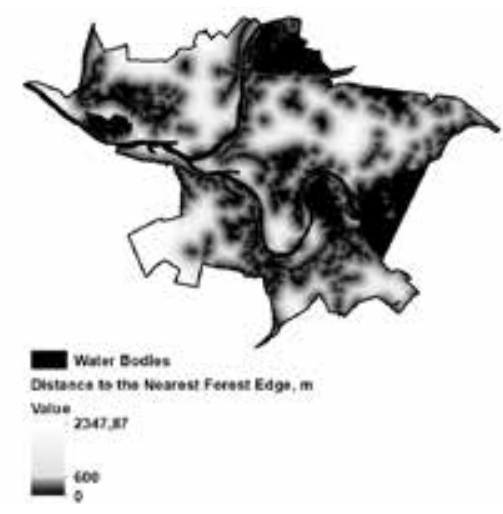

a)

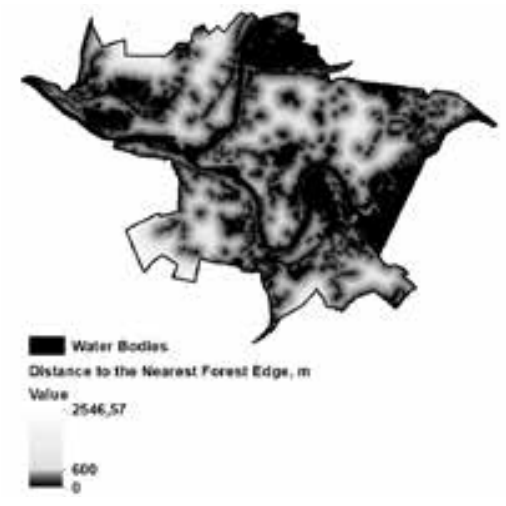

Figure 2. Spatial structure of forest land in Kaunas city: a) in 1950; b) in 2011.

b)

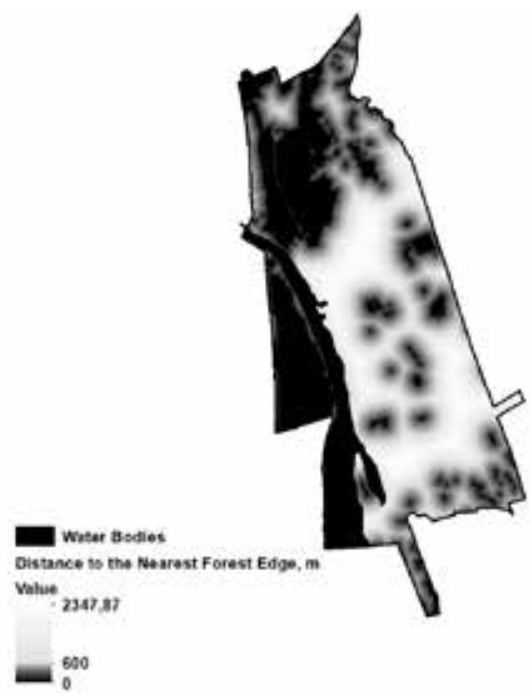

a)

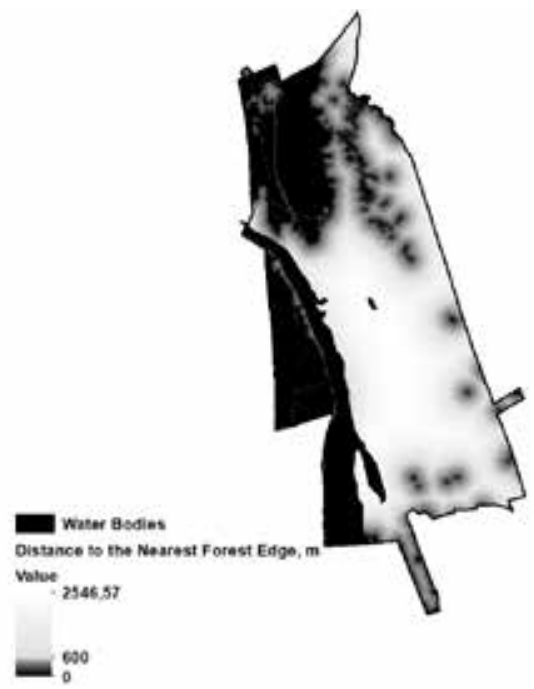

Figure 3. Spatial structure of forest land in Klaipeda city: a) in 1950; b) in 2011.

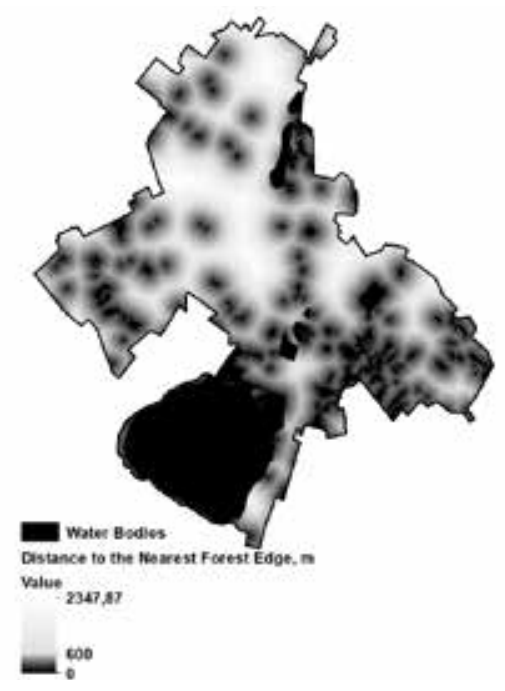

a) $\quad=0$

b)

Figure 4. Spatial structure of forest land in Šiauliai city: a) in 1950; b) in 2011.

of the raster to the forest land in the forested area is zero $(0.0 \mathrm{~m}))$.

The spatial structure of the forest land in Vilnius city was not significantly different neither in 1950 nor in 2011 (Fig. 1).

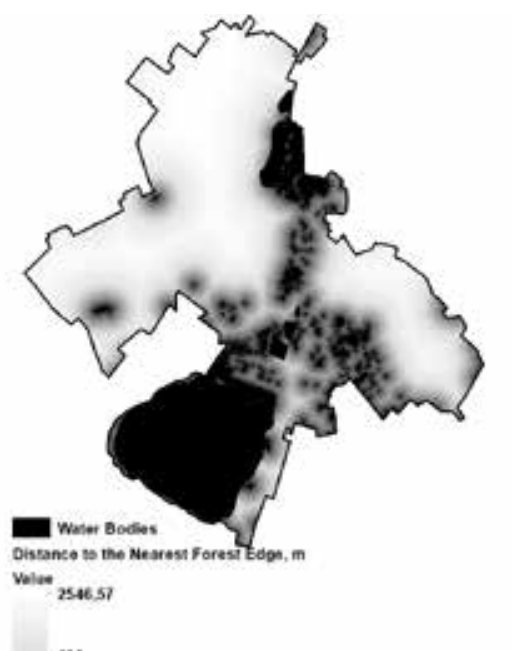

b)

Since the area of forest land increased by $9.5 \%$ in Vilnius city, we may conclude that afforestation process was developed in high accuracy and enough precision. The increase of urban surfaces in Vilnius city didn't affect spatial structure of the forest land. 


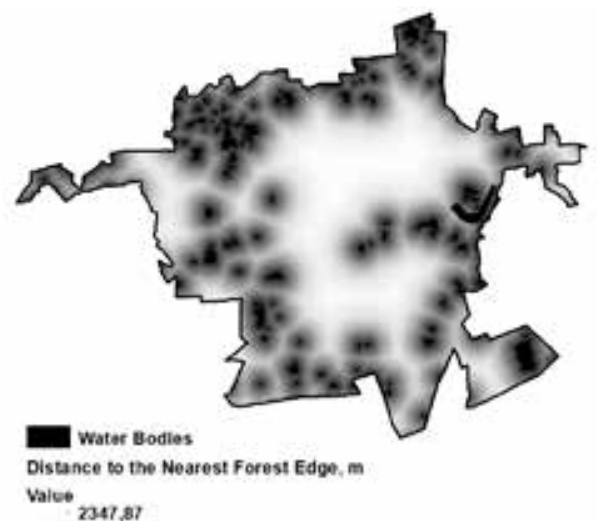

a)

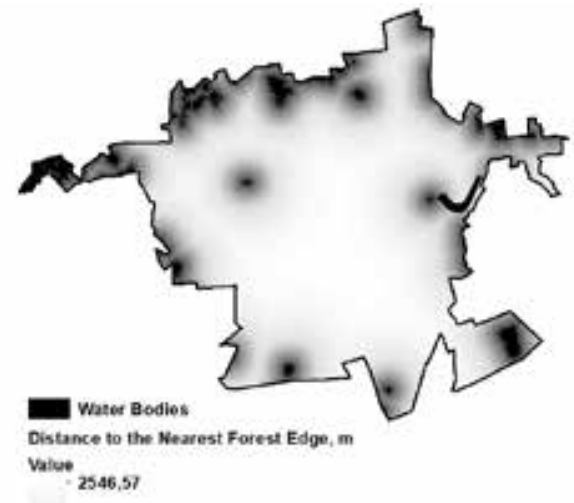

b)

Figure 5. Spatial structure of forest land in Panevėžys city: a) in 1950; b) in 2011.
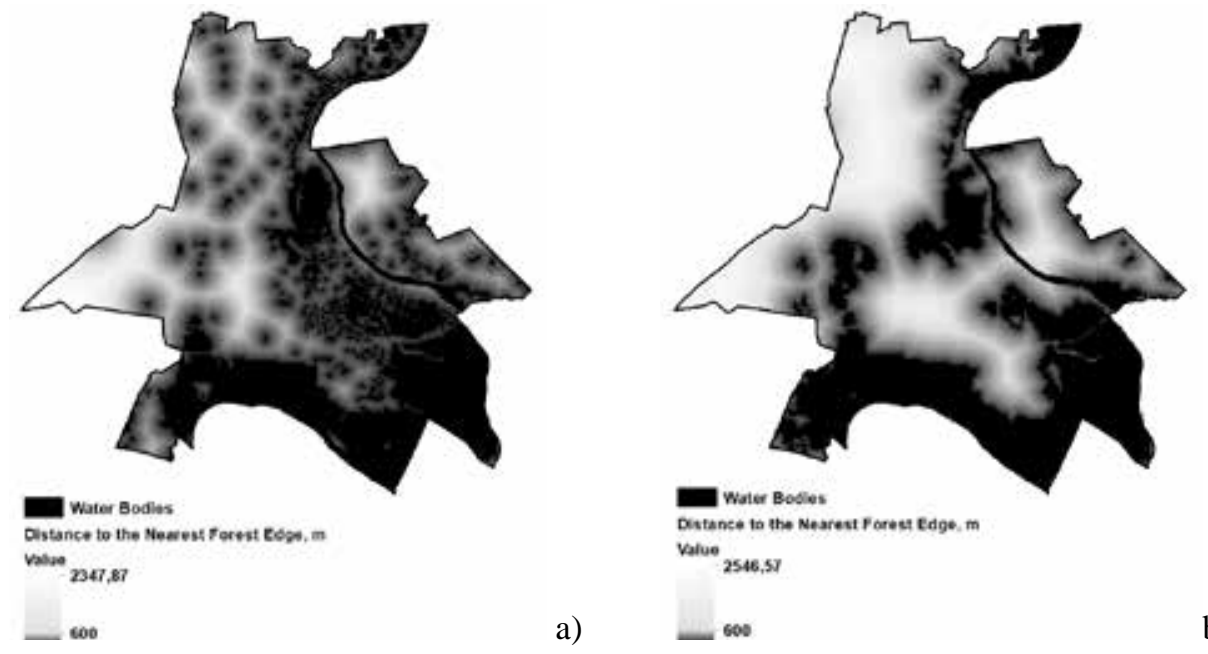

Figure 6. Spatial structure of forest land in Alytus city: a) in 1950; b) in 2011.

No significant changes were detected evaluating spatial structure of forest land in Kaunas city during the investigated period either (Fig. 2). Grids of Euclidean distance of the cells to nearest forests representing the spatial structure of forest land in 1950 and 2011 were similar enough. Since the area of the forest land increased by $5.3 \%$ in the period 1950 2011, the spatial structure of the forest land in Kaunas city as well as Vilnius city is more optimal than in 1950. Obviously, more urban lands were afforested in the central part of Kaunas city.

Even the area of the forest land increased by $1.7 \%$ in Klaipeda city during the investigated period, the spatial structure of the forest land tended to degrade (Fig. 3). The central part of Klaipeda city forced deforestation due to urbanization.

Obviously, the spatial structure of the forest land in Šiauliai city tended to degradation despite the increase of the forest land area by $0.8 \%$ (Fig. 4).

The increase of urban surfaces in Panevėžys city induced noticeable disturbance on the forest land spatial structure (Fig. 5).

Grids of Euclidean distance of the cells to nearest forests representing the spatial structure of forest land in Alytus city in 1950 and 2011 differed (Fig. 6). Small areas of the forest land were lost due to the urbanization process despite the increase of forest land area by $4.1 \%$.

\section{Conclusions}

1. Areas of the forest land increased in all investigated cities during the period 1950 - 2011, excluding Panevėžys city. The increases of areas of the forest land varied from $0.8 \%$ to $9.5 \%$. The largest increase was found in Vilnius city (9.5\%), the smallest - in Šiauliai city $(0.8 \%)$. The decrease by $0.9 \%$ of the forest land was found in Panevėžys city.

2. No significant changes of the forest land spatial structure were found in the largest cities of Lithuania, i. e. Vilnius city and Kaunas city during the period 1950 - 2011. Grids of Euclidean distance of the cells to nearest forests representing the spatial structure of forest land were quite similar in both cities.

3. The increase of urban surfaces induced disturbance on the forest land spatial structure in Klaipeda, Šiauliai, Panevėžys and Alytus cities. 


\section{References}

1. Alberti, M., \& Marzluff, J.M. (2004). Ecological resilience in urban ecosystems: Linking urban patterns to human and ecological functions. Urban Ecosystems. 7(3), 241-265.

2. Chiesura, A. (2004). The role of urban parks for the sustainable city. Landscape and Urban Planning. 68 (1), 129-138. DOI: 10.1016/j.landurbplan.2003.08.003.

3. Daniels, B., Zaunbrecher, B.S., Paas, B., Ottermanns, R., Ziefle, M., \& Roß-Nickoll, M. (2018). Assessment of urban green space structures and their quality from a multidimensional perspective. Science of The Total Environment. 615, 1364-1378. DOI: 10.1016/j.scitotenv.2017.09.167.

4. Dyderski, M.K., Tyborski, J., \& Jagodziński, A.M. (2017). The utility of ancient forest indicator species in urban environments: A case study from Poznań, Poland Original. Urban Forestry \& Urban Greening. 27, 76-83.

5. Grigorescu, I., \& Geacu, S. (2017). The dynamics and conservation of forest ecosystems in Bucharest Metropolitan Area. Urban Forestry \& Urban Greening. 27, 90-99.

6. Juknelienè, D., \& Mozgeris, G. (2015). The spatial pattern of forest cover changes in Lithuania during the second half of the twentieth century“. Žemès ūkio mokslai. 22(4), 209-215.

7. Juknelienè, D., Valčiukienè, J., \& Atkocevičienè, V. (2017). Assessment of regulation of legal relations of territorial planning: A case study in Lithuania. Land Use Policy. 67, 65-72. DOI: 10.1016/j. landusepol.2017.05.019.

8. Lietuvos Respublikos Seimas. (1995). Lietuvos Respublikos teritoriju planavimo istatymas. Nr. 107-2391 (Republic of Lithuania Law on Territorial Planning). Valstybės žinios. (in Lithuanian).

9. Mozgeris, G. (2012). Miško žemès plotu kaitos Lietuvoje 1990-2011 m. ivvertinimas: atsiskaitomuju dokumentu rinkinys (Assessment of Forest Land Cover Changes in Lithuania during the Period 1990_ 2011: settlement documents). Akademija, Kaunas dist.: Lithuanian association of impartial timber scalers. 100 p. (in Lithuanian).

10. Ruseckas, J., \& Tiškutè-Memgaudienè, D. (2013). Teritorijos miškingumo įtaka kritulių kiekiui (The influence of the forest coverage of territory on the precipitation). Miškininkysté. 1(73), 19-30. (in Lithuanian).

11. Tiškutè-Memgaudienè, D., \& Ruseckas, J. (2014). The influence of forest distribution in the landscape of Lithuania on the precipitation amount. In Annual 20th International Scientific Conference Proceedings 'Research for Rural Development' (Volume 2), 21-23 May 2014. (pp. 28-34). Jelgava, Latvia.

12. Vaitekūnas, S. (2002). Lietuvos gyventojų skaičiaus kaita ir priežastys nepriklausomybės laikotarpiu (Changes of Lithuanian population in the number of people and reasons for population changes during the period of independence). Tiltai. 1-16. (in Lithuanian). 